\title{
KEARIFAN LOKAL DALAM USAHA TANI UBI JALAR DI KELURAHAN KOYA KECAMATAN TONDANO SELATAN KABUPATEN MINAHASA
}

\author{
Maiter Uaga \\ Melsje Yellie Memah \\ Jean Fanny Junita Timban
}

\begin{tabular}{lll}
\hline Naskah diterima melalui Website Jurnal Ilmiah agrisosioekonomi@ unsrat.ac.id & $:$ & Jumat, 13 Desember 2019 \\
Disetujui diterbitkan & $:$ & Selasa, 31 Desember 2019 \\
\hline
\end{tabular}

\begin{abstract}
This study aims to determine the local wisdom of sweet potato farming in the Koya Village. This research was conducted in Koya Village, South Tondano District, Minahasa Regency. Sampling using a purposive sampling method, deliberately chose farmers who cultivate sweet potatoes as many as 10 people who are local sweet potato farmers. The data collected is primary data and secondary data. Primary data data obtained from interviews with sweet potato farmers with the help of a list of questions. Secondary data were obtained from the Koya Kelurahan government, as well as scientific papers related to research. The results showed that local wisdom in sweet potato farming in Koya Village was in the process of preparing land where farmers could differentiate land based on the color and type of soil so as to produce good sweet potatoes. In tillage, sweet potato farmers provide grain from the remnants of rice so that the soil can be fertile and the sweet potato produced is large and makes it easier to harvest. ${ }^{*}$ prm*
\end{abstract}

Keywords: sweet potato, local wisdom, farming

\begin{abstract}
ABSTRAK
Penelitian ini bertujuan untuk mengetahui kearifan lokal usaha tani ubi jalar di Kelurahan Koya. Penelitian ini dilakukan di Kelurahan Koya Kecamatan Tondano Selatan Kabupaten Minahasa. Pengambilan sampel mengunakan metode purposive sampling, secara sengaja memilih petani yang mengusahakan ubi jalar sebanyak 10 orang yang merupakan petani ubi jalar setempat. Data yang dikumpulkan adalah data primer dan data sekunder. Data primer data yang diperoleh dari wawancara pada petani ubi jalar dengan bantuan daftar pertanyaan. Data sekunder diperoleh dari pemerintah Kelurahan Koya, serta karya tulis ilmiah yang berhubungan dengan penelitian. Hasil penelitian menunjukkan bahwa kearifan lokal dalam usaha tani ubi jalar di Kelurahan Koya yakni pada proses penyiapan lahan dimana petani dapat membedakan tanah berdasarkan warna dan jenis tanah sehingga dapat menghasilkan ubi yang bagus. Pada pengolahan tanah petani ubi jalar memberikan gabah dari sisa-sisa padi agar tanah dapat subur dan ubi jalar yang dihasilkan besar serta memudahkan saat panen. ${ }^{*}$ prm*
\end{abstract}

Kata Kunci: ubi jalar, kearifan lokal, usaha tani

Agrisosioekonomi:

Jurnal Transdisiplin Pertanian (Budidaya Tanaman, Perkebunan, Kehutanan, Peternakan, Perikanan), Sosial dan Ekonomi 


\section{PENDAHULUAN}

\section{Latar Belakang}

Kearifan lokal dalam usaha tani ubi jalar di Kelurahan Koya Kecamatan Tondano Selatan, suda lama dikenal oleh petani sendiri sehingga petani melakukan dengan pemilihan lahan sampai panen yaitu pemilihan lahan, pembersihan, pengolahan tanah, mempersiapkan bibit ubi jalar, penanaman, perawatan, hingga pemanenan. Untuk itu petani di Kelurahan Koya sudah lama mengembangkan ubi jalar secara subsistem, oleh karena itu petani menggunakan kearifan lokal sebagai upaya untuk memenuhi kebutuhan sampingan. Maka hasil panen yang meningkat dapat pula sebagian besar dijual untuk mencukupi kebutuhan sehari-hari, dan biaya untuk anak-anak sekolah.

Kearifan lokal dalam usaha tani ubi jalar yang mana telah diterapkan oleh petani di Kelurahan Koya secara turun-temurun yang mampu memperbaiki dalam artian mengubah keadaan atau kondisi petani. Salah satu faktor untuk melakukan peran dominannya meliputi sosial, ekonomi, dan kebijakan politik seperti tradisi dan agama atau kepercayaan, harga dan kemudahan transportasi dan eksistensi saluran pemasaran, stabilitas harga dan tersedianya modal dan kredit.

Widyastuti, (1994) menunjukkan bahwa transfer kearifan lokal budidaya ubi jalar oleh petani melalui pengamatan terhadap model/figur tertentu, yaitu dengan menirukan perilaku model/ figur tersebut, sebagai proses pembelajaran sosial. Proses ini tidak dilakukan dalam waktu singkat, tetapi berlangsung sepanjang kehidupan seseorang, yaitu melewati tahapan perhatian (atensi), penyimpanan dalam ingatan (retensi), dan peniruan (reproduksi motorik). Untuk mengatasi hal tersebut, ada banyak hal yang dapat dilakukan, antara lain dengan mengintroduksi teknologi budidaya ubi jalar yang dapat meningkatkan produksinya.

Petani di Kelurahan Koya masih menggunakan kearifan lokal dalam mengusahakan ubi jalar agar mengintroduksi teknologi baru, seorang agen pembangunan perlu mengetahui proses transfer pengetahuan yang efektif di antara petani. Usaha tani ubi jalar merupakan komoditas sumber karbohidrat utama, setelah padi, singkong, terigu dan jagung dan ubi jalar juga mempunyai peranan penting dalam penyediaan bahan pangan, bahan baku industri maupun pakan ternak. Petani Kelurahan Koya sebagian besar mengkonsumsi ubi jalar sebagai makanan tambahan dalam bentuk camilan maupun lauk pauk sehingga peranannya sebagai penyedia gizi yang dapat dijangkau masyarakat perdesaan cukup tinggi dalam pengembangan usaha tani ubi jalar merupakan salah satu komoditas pangan yang mempunyai keunggulan sebagai penunjang program tersebut (Sasongko, et al., 2008).

Ubi jalar merupakan bahan yang baik karena mengandung karbohidrat tinggi dan sumber vitamin A terutama pada varietas yang mempunyai warna umbi kuning kemerahmerahan, Ubi jalar (Ipomoea batatas), atau dikenal juga dengan istilah ketela rambat merupakan tanaman yang termasuk ke dalam jenis tanaman palawija, dapat berfungsi sebagai pengganti bahan makanan tambahan (beras) karena merupakan sumber karbohidrat. Di Kelurahan Koya merupakan daerah yang bercocok tanam ubi jalar dan penghasil komoditas ubi jalar terbesar. Produksi ubi jalar meningkat dengan rata-rata $90 \%$. memegang peranan yang cukup penting karena mempunyai banyak manfaat dan nilai tambah.

Usaha tani ubi jalar merupakan salah satu penghasil karbohidrat (sebagai sumber energi) yang potensial dan dapat digunakan sebagai sumber pangan alternatif (selain nasi), bahan pembuatan pakan dan bahan industri. Nilai tambah dari ubi jalar cukup banyak yang dapat diperoleh dengan cara pengolahan ubi jalar segar menjadi tepung, selai, keripik, mie, sitk dan saos., gula permanen, obat-obatan, cuka, manisan kering, kecap, lem, dan pakan. Varian dari tepung ubi jalar diantaranya: kue kering (cookies), kue bolu (cake), (ice cream), roti manis, (juice), dan bakpia.

Peranan usahatani ubi jalar memiliki prospek yang baik sebagai komoditas pertanian unggulan tanaman palawija. Potensi produksi bisa mencapai 25-40 ton per hektar dan saat ini ubi jalar merupakan tanaman ubi-ubian yang paling produktif. Menurut data BPS Indonesia (2010), luas panen dan produksi ubi jalar di Kelurahan Koya mencapai 2 ha dengan produksi 89.75 ton dan produktivitas mencapai 136,23 ha penyumbang produksi terbesar di Indonesia. 
Daerah penyebaran sentra komoditas ubi jalar tiga terbesar di Kelurahan Koya produksi tertinggi di Kelurahan Koya masih jauh dari potensi yang seharusnya, potensi produksivitas ubi jalar bisa mencapai 25-40 ton/ha, meskipun produktivitas ubi jalar di Kelurahan Koya secara finansial usahatani ubi jalar.

Usaha tani ubi jalar merupakan salah satu bahan pangan yang utama, tidak saja di Indonesia tetapi juga di dunia, di Indonesia ubi jalar merupakan makanan tambahan nasi salah satunya di kabupaten Minahasa Propinsi Sulawesi Utara yang memiliki tingkat produksi ubi jalar cukup tinggi, produksi ubi jalar mencapai 375 ton dengan luas panen 28, 1 ha kemudian meningkat pada ubi jalar merupakan salah satu tanaman palawija yang memiliki potensi besar dalam perkembangan sektor pertanian di Minahasa, lebih khususnya di Kelurahan Koya Kecamatan Tondano Selatan Kabupaten Minahasa, merupakan salah satu tingkat produksi ubi jalar mereka memiliki potensi yang besar sehingga meningkat setiap tahun, tingkat produksi ubi jalar mencapai 30 ton per hektar. Meski dengan produksi yang terus meningkat hal ini tidak berbanding lurus dengan pendapatan petani ubi jalar tersebut sehingga kesejahteraan masyarakat kehidupan petani masih harus ditingkatkan.

Berbagai program sudah dilakukan oleh pemerintah salah satunya melalui kegiatan partisipasi masyarakat dalam usaha tani ubi jalar untuk itu pemerintah meluncurkan melalui berbagai program mengadakan kegiatan usaha tani maka diharapkan dapat membantu petani agar meningkatkan pendapatannya sangat memuaskan berdasarkan hal tersebut, maka sangat penting untuk diteliti peranan penyuluhan terhadap pendapatan usahatani petani ubi jalar, itulah sebabnya salah satu jenis tanaman pangan yang sudah lama dikenal dan di budidayakan oleh petani di Kelurahan Koya adalah ubi jalar. Potensi ini nilai ekonomi dan sosial ubi jalar merupakan bahan pangan masa depan yang berdaya guna, bahan baku berbagai industri dan bahan ternak.

\section{Kearifan Lokal Ubi Jalar}

Kearifan Lokal Ubi Jalar dalam kehidupan masyarakat dikembangkan oleh petani kecil dalam kondisi tertentu. Kearifan lokal budidaya ubi jalar di kalangan petani meliputi pemilihan lahan, pembersihan lahan, penebangan pohon besar dan pembakaran, penyimpanan bahan tanam, penanaman, pemanenan, dan pembukaan kebun baru (Jamrianti, R.2009).

\section{Rumusan Masalah}

Berdasarkan latar belakang maka yang menjadi masalah dalam penelitian ini adalah bagaimana kearifan lokal dalam usaha tani ubi jalar di Kelurahan Koya Kecamatan Tondano Selatan Kabupaten Minahasa.

\section{Tujuan Penelitian}

Tujuan dari penelitian ini untuk mengetahui kearifan lokal usaha tani ubi jalar di Kelurahan Koya Kecamatan Tondano Selatan Kabupaten Minahasa.

\section{Manfaat Penelitian}

bagi:

Penelitian ini diharapkan dapat bermanfaat

1. Masyarakat

Menambah pengetahuan kepada masyarakat agar masyarakat dapat memahami tentang usaha tani ubi jalar secara detail.

2. Penulis

Selain untuk penyelesaian studi akhir, juga dapat menambah pemahaman dan pengetahuan kepada penulis tentang bagaimana tanggapan masyarakat terhadap usaha tani ubi jalar.

\section{METODE PENELITIAN}

\section{Tempat dan Waktu Penelitian}

Penelitian ini berlangsung selama 3 bulan sejak bulan April sampai bulan Juni 2019. Tempat penelitian di Kelurahan Koya Kecamatan Tondano Selatan Kabupaten Minahasa.

\section{Metode Pengambilan Data}

Data yang digunakan dalam penelitian ini adalah data primer dan data sekunder. Data primer data yang diperoleh dari tempat penelitian melalui daftar pertanyaan atau kuesioner. Data sekunder data yang diperoleh dari pemerintah Kelurahan Koya, serta karya tulis ilmiah yang berhubungan dengan penelitian.

\section{Metode Pengambilan Sampel}

Pengambilan sampel mengunakan metode purposive sampling, secara sengaja memilih petani yang mengusahakan ubi jalar sebanyak 10 orang yang merupakan petani setempat. 


\section{Konsep Pengukuran Variabel}

1. Karakteristik Responden:
a. Nama Responden
b. Umur Responden
c. Pekerjaan Responden
d. Tingkat Pendidikan Responden

2. Kearifan lokal dalam usaha tani ubi jalar:
a. Pemilihan Lahan
b. Pembersihan Lahan
c. Pengolahan Tanah
d. Penyiapan Bahan
e. Penanaman
f. Pemeliharaan Kebun
g. Pemanenan

\section{Metode Analisis Data}

Metode analisis data yang digunakan dalam penelitian adalah analisis deskriptif dan di sajikan dengan mengunakan tabel.

\section{HASIL DAN PEMBAHASAN}

\section{Deskripsi Lokasi Penelitian}

\section{Letak Geografis, dan Luas Wilayah, Batas} Administrasi

Kelurahan Koya adalah salah satu kelurahan yang terletak di Kecamatan Tondano Selatan Kabupaten Minahasa Provinsi Sulawesi Utara, dengan luas wilayah di Kelurahan Koya adalah 554.39.6 Km, dengan batas wilayah:

- Sebelah Timur : Kelurahan Tataaran I

- Sebelah Barat : Kelurahan Tataaran II

- Sebelah Utara : Kelurahan Tataaran Barat

- Sebelah Selatan : Kelurahan Tonsaru

Secara administratif Kelurahan Koya terdiri dari 6 jaga yaitu jaga 1 sampai jaga 6 , Curah hujan 500 Mm, Jumlah Bulan Hujan 6-8 bulan, Kelembaban $239 \mathrm{Mm}$, Suhu rata-rata harian $53^{\circ} \mathrm{C}$.

\section{Jumlah Penduduk di Kelurahan Koya}

Berdasarkan data Pemetaan jumlah penduduk di Kelurahan Koya sebanyak 733 jiwa dengan jumlah kepala keluarga (KK) $354 \mathrm{KK}$, yang menempati 6 jaga.
Tabel 1. Jumalah Penduduk di Kelurahan Koya

\begin{tabular}{cccccccc}
\hline No. & Jaga & L & P & Jumlah & $\begin{array}{c}\text { Persentase } \\
(\%)\end{array}$ & $\begin{array}{c}\text { Jumlah } \\
(\text { KK) }\end{array}$ & $\begin{array}{c}\text { Persentase } \\
(\%)\end{array}$ \\
\hline 1. & I & 50 & 43 & 93 & 12,6 & 39 & 11,1 \\
2. & II & 63 & 50 & 113 & 15,4 & 66 & 18,1 \\
3. & III & 80 & 60 & 140 & 19,1 & 43 & 12,14 \\
4. & IV & 74 & 53 & 127 & 17,3 & 75 & 21,18 \\
5. & V & 90 & 76 & 166 & 22,6 & 81 & 22,8 \\
6. & VI & 56 & 38 & 94 & 13,8 & 50 & 15 \\
\hline \multicolumn{7}{l}{ Total } \\
\hline \multicolumn{7}{l}{ Sumber Data dari kantor Kelurahan Koya 2019. }
\end{tabular}

Tabel 1 dapat diketahui bahwa jumlah penduduk laki-laki sangat besar dari pada jumlah penduduk perempuan. Jumlah penduduk lakilaki yang lebih banyak yaitu 413 sedangkan jumlah perempuan 320 orang, maka penjelasan disini bahwa jumlah yang tertinggi adalah lakilaki.

\section{Jenis Pekerjaan Penduduk Di Kelurahan Koya}

Menurut pekerjaan penduduk di Kelurahan Koya dapata diketahi bahwa memiliki pekerjaan yang berbeda yang kerja dalam setiap bidang sesuai latar belakang pendidikan.

Tabel 2. Jenis Pekerjaan Penduduk Di Kelurahan Koya

\begin{tabular}{lc}
\multicolumn{1}{c}{ Koya } & \\
\hline Jenis & Jumlah (Orang) \\
Pekerjaan & 6 \\
\hline Kepala & \\
lingkugan & 9 \\
PNS & 9 \\
Sopir & 80 \\
Guru & 8 \\
TNI/POLRI & 80 \\
Abang ojek & 69 \\
Petani sawah & 73 \\
Nelayan & 35 \\
Tukang kayu & 10 \\
Petani & $\mathbf{3 7 9}$ \\
\hline TOTAL & \\
\hline Sumber Data: Diolahi
\end{tabular}

Sumber Data: Diolah dari Data Primer,2019

Tabel 2 dapat diketahui bahwa, jenis pekerjaan penduduk di kelurahan koya yaitu PNS 9 orang, sopir 9 orang, guru 80 orang, TNI/POLRI 8 orang, abang ojek 80 orang, petani sawa 69 orang, nelayan 73 orang, tukang kayu 35 orang, petani ubi jalar 10 orang, kepala lingkungan 6 orang. 


\section{Karakteristik Responden Umur Responden}

Umur merupakan salah satu faktor yang mempengaruhi tingkat produktivitas petani pada usaha tani Ubi jalar. Perbedaan umur juga berpengarug terhadap kedudukan dan derajat seseorang, dimana perbedaannya adalah usia tua dan muda, maka produktivitas seseorang dapat dipengaruhi oleh umur, yaitu umur yang lebih muda tingkat produktivitasnya tinggi sedangkan umur yang lebih tua tingkat produktivitas lebih rendah. Umur responden secara rinci dapat dilihat pada Tabel 3.

\begin{tabular}{cccc}
\multicolumn{5}{l}{ Tabel 3. Umur Responden } \\
\hline No. & Umur & Jumlah (Orang) & Persen (\%) \\
\hline 1. & $\leq 40$ & 1 & 10 \\
2. & $41-50$ & 6 & 60 \\
3. & $51-60$ & 3 & 30 \\
4. & $>61$ & 0 & 0 \\
\hline & Total & $\mathbf{1 0}$ & $\mathbf{1 0 0}$ \\
\hline
\end{tabular}

Sumber Data: Diolah dari Data Primer, 2019

Tabel 3 menunjukan bahwa umur $\leq 40$ tahun sebanyak 1 orang dengan persentase $10 \%$, umur $41-50$ tahun sebanyak 6 orang dengan persentase $60 \%$, umur $51-60$ tahun sebanyak 3 orang dengan persentase $30 \%$ dan umur $>60$ tahun berjumlah nol atau tidak ada. Maka persentase umur yang terbanyak adalah $60 \%$.

\section{Tingkat Pendidikan Responden}

Salah satu faktor yang mempengaruhi pada tingkat pengetahuan adalah tingkat pendidikan, maka pendidikan semakin berkembang dan semakin meningkat, awalnya latar belakang pendidikan mereka, mempunyai pengetahuan yang luas mengenai pengembangan keatifan lokal, maka pendidikan sangat penting karena begitu memiliki pengetahuan yang begitu luas maka bisa berkomunikasi dengan berbagai konsumen dan bisa menangkapi dengan secepatnya.

Tabel 4. Jumlah Responden Menurut Pendidikan

\begin{tabular}{cccc}
\hline No. & $\begin{array}{c}\text { Tingkat } \\
\text { Pendidikan }\end{array}$ & Jumlah (Orang) & Persen (\%) \\
\hline 1. & SD & 3 & 30 \\
2. & SMP & 3 & 30 \\
3. & SMA & 4 & 40 \\
\hline & Total & 10 & 100 \\
\hline
\end{tabular}

Sumber Data: Diolah dari Data Primer, 2019
Tabel 4 menunjukan bahwa responden yang tingkat pendidikannya SD sebanyak 3 orang dengan persentase $30 \%$, lalu responden yang tingkat pendidikan SMP sebanyak 3 orang dengan persentase $30 \%$, dan responden dengan tingkat pendidikan SMA sebanyak 4 orang dengan persentase $40 \%$.

\section{Kearifan Lokal Dalam Usaha Tani Ubi Jalar di Kelurahan Koya}

Kearifan lokal dalam usaha tani ubi jalar adalah seperangkat pengetahuan dan teknologi yang tersimpan dalam memori dan dilakukan dalam kehidupan masyarakat dan dikembangkan oleh petani itu sendiri dalam kondisi tertentu. Kearifan lokal dalam usaha tani ubi jalar di kalangan petani meliputi pemilihan lahan, pembersihan lahan, dan penyiapan bahan tanam, penanaman, sampai pemanenan.

\section{Pemilihan Lahan}

Pemilihan lahan sangat penting bagi setiap petani, dimana pemilihan lahan yang baik maka ketika membuat bedengan dan menanam berbagai jenis tanaman akan bertumbuh dengan sempurna maka petani responden dalam pemilihan lahan tanah memilih yang paling cocok.

Tabel 5. Pemilihan Lahan Petani Ubi di Kelurahan Koya

\begin{tabular}{cccc}
\hline \multirow{2}{*}{ Responden } & \multicolumn{3}{c}{ Memilih Lahan } \\
\cline { 2 - 4 } & $\begin{array}{c}\text { Warna } \\
\text { Tanah }\end{array}$ & Jenis Tanah & $\begin{array}{c}\text { Sifat } \\
\text { Tanah }\end{array}$ \\
\hline 1. & - & - & Ada \\
2. & Ada & - & - \\
3. & Ada & - & - \\
4. & - & Ada & - \\
5. & - & - & Ada \\
6. & - & Ada & - \\
7. & - & - & Ada \\
8. & Ada & - & - \\
9. & Ada & - & - \\
10. & & Ada & - \\
\hline Total & $\mathbf{4}$ & $\mathbf{3}$ & $\mathbf{3}$ \\
\hline
\end{tabular}

Sumber Data: Diolah dari Data Primer, 2019

Tabel 5 menunjukkan bahwa dalam pemilihan lahan petani memiliki 3 cara pemilihan lahan. 4 responden memilih lahan dengan cara melihat warna tanah yaitu warna tanah merah. 3 responden memilih lahan dengan cara memilih jenis tanah dan jenis tanah yang 
dipilih adalah jenis tanah kerikil. 3 responden memilih sifat tanah. Dan petani pemilihan lahan karena tanaman ubi jalar membutuhkan tanah yang subur, gembur, banyak mengandung bahan organik, agar drainasenya baik dengan reaksi tanah $(\mathrm{PH})$ 5-6,5 jenis tanah yang paling baik adalah Andosol dengan ciri-ciri solum tanah agak tebal antara 1-2 meter, berwarna hitam atau kelabu sampai coklat tua, bertekstur debu atau lempung berdebu sampai lempung. Jenis tanah Andosol memiliki kandungan unsur hara sedang sampai tinggi, produktivitas sedang sampai tinggi dan reaksi tanah masam sampai netral.

\section{Pembersihan Lahan}

Proses pembersihan lahan petani mempersiapkan alat-alat, antara lain, parang, sekop dan cangkul sesudah itu memulai proses pembersihan lahan dengan istilah babat atau di cangkul tujuan dari tahapan ini untuk membersihkan semak-semak dan rumput-rumput yang tumbuh di area lahan tersebut, sehingga petani harus membersihkan lahan dengan baik, agar pada saat pengolahan tanah atau membuat bedengan dengan mudah dan proses pertumbuhan ubi jalar dengan baik.

\begin{tabular}{cccc}
\multicolumn{3}{c}{$\begin{array}{c}\text { Tabel 6. Pembersihan Lahan Pertani Ubi Jalar di Kelurahan } \\
\text { Koya }\end{array}$} & \multicolumn{3}{c}{ Alat Yang Digunakan } \\
\hline \multirow{2}{*}{ Responden } & & \multicolumn{3}{c}{ Parang } & Sekop \\
\cline { 2 - 4 } & Cangkul & - & - \\
2. & Ada & ada & - \\
3. & - & - & - \\
4. & Ada & Ada & - \\
5. & - & - & Ada \\
6. & - & - & - \\
7. & Ada & Ada & - \\
8. & Ada & - & - \\
9. & - & Ada & Ada \\
\hline 10. & - & - & $\mathbf{2}$ \\
\hline Total & $\mathbf{4}$ & $\mathbf{4}$ & \\
\hline Sumber Data: Diolah dari Data Primer, 2019 & &
\end{tabular}

Tabel 6 menunjukkan bahwa proses pembersihan lahan pertanian ubi jalar petani memiliki alat yang berbeda, yaitu dimana ada 4 responden yang memiliki cangkul, 4 responden yang memiliki parang, responden yang memiliki sekop mekanisme pertanian sangat diperlukan untuk mempercepat proses pembukaan lahan yang aman, agar cepat lahan tidur dengan rumput atau alang-alang, semak-semak atapun rumput yang tebal. Rumput-rumpat dapat dilakukan dengan mengunakan parang dan cangkul, dalam pembersihan lahan melakukan dengan teratur maka ketiga melakukan proses pengolahan tanah dilakukan dengan baik.

\section{Pengolahan Tanah}

Proses pengolahan tanah petani memiliki berbeda teknik dalam pengolahan tanah, salah satu kegiatan persiapan lahan yang bertujuan untuk menciptakan kondisi lingkungan yang sesuai untuk pertumbuhan tanaman. Pengolahan tanah dapat memperbaiki daerah perakaran tanaman, kelembaban dan aerasi tanah mempercepat infiltrasi serta mengendalikan tumbuhan pengganggu.

\begin{tabular}{cccc} 
Tabel 7. Pengolahan Tanah & \multicolumn{2}{l}{ Alat Yang Digunakan } & $\begin{array}{c}\text { Bahan Yang } \\
\text { Digunakan }\end{array}$ \\
\cline { 2 - 4 } Responden & Cangkul & Bajak Sapi & Gabah Padi \\
\cline { 2 - 4 } 2. & - & Ada & Ada \\
3. & Ada & - & Ada \\
4. & Ada & - & Ada \\
5. & - & Ada & Ada \\
6. & Ada & - & Ada \\
7. & - & Ada & Ada \\
8. & - & Ada & Ada \\
9. & Ada & - & Ada \\
10. & Ada & - & Ada \\
\hline Total & - & Ada & Ada \\
\hline Sumber Data: Diolah dari Data Primer, 2019 & $\mathbf{1 0}$ \\
\hline
\end{tabular}

Tabel 7 menunjukkan bahwa proses pengolahan tanah dilakukan responden dengan menggunakan cangkul dan bajak sapi. Cangkul digunakan oleh 5 responden sedangkan bajak sapi digunakan oleh 5 responden. Gabah padi digunakan 10 responden untuk proses penyuburan tanah dan tanaman agar ubi jalar yang dihasilkan lebih besar.

a. Cangkul adalah salah satu jenis alat pertanian tradisional yang digunakan dalam proses pengolahan tanah pada lahan pertanian. Cangkul digunakan untuk menggali, mencungkil, ataupun untuk meratakan tanah. Cangkul masih digunakan sehingga masa 
ini untuk menjalankan kerja-kerja menggali yang ringan di kebun ataupun di sawah. Alat ini merupakan elemen penting dalam bidang pertanian terutama pertanian ladang kering. Fungsi tangkai cangkul: Untuk memegang dan mengayunkan mata cangkul sewaktu digunakan dalam bekerja. Bagianbagian cangkul: Bagian tangkai dari kayu bentuk tangkai lurus dan bengkok, bagian mata cangkul dari besi. Fungsi mata cangkul: membalik tanah, menghaluskan tanah, mencampur pupuk gabah. Ukuran dan bentuk cangkul bervariasi hal ini tergantung pada kondisi dan jenis tanah setempat.

b. Bajak sapi adalah salah satu jenis alat pertanian tradisional yang digunakan dalam proses pengolahan tanah pada lahan pertanian. Bajak sapi digunakan untuk menggali, mencungkil, ataupun untuk meratakan tanah sehingga petani melakukan pengolahan tanah dengan tenaga dua ekor bajak sapi, kedua sapi menarik alat bajak pada ujungnya. Dengan bajak sapi ini pengolahan tanah dilakukan hingga beberapa kali, sehingga tanah menjadi lembut agar mempermudah akar tanaman berkembang. Selain diolah dengan bajak, tanah juga diinjak-injak sapi. Pengolahan seperti ini dianggap lebih bagus dibanding menggunakan cangkul.

\section{Penyiapan Bibit Tanam}

Proses penyiapan bibit ubi jalar dapat dibuat dengan mudah menggunakan stek pucuk atau batang, umbi, dan biji. Stek pucuk atau batang paling efesien digunakan untuk tujuan produksi. proses penyiapan bibit tanam ubi jalar diambil dari stek yang paling cocok untuk tujuan produksi umbi, pertumbuhan tanaman ubi jalar asal stek pucuk atau batang lebih seragam, selain itu kemampuan untuk menghasilkan umbi relatif lebih baik jika dibandingkan dengan stek dari umbi atau biji.
Stek dapat diambil dari tanaman produksi yaitu tanaman yang dibudidayakan untuk memproduksi umbi atau dari tanaman persemaian yang khusus ditanam untuk menghasilakan stek. Stek dapat mulai diambil ketika tanaman berumur antara 2-3 bulan, yaitu ketika laju pertumbuhan tanaman kuat dan cepat, jumlah stek yang diambil dari masing-masing tanaman muda cukup satu atau dua saja agar tidak berpengaruh terhadap penurunan hasil dan kualitas umbi, apabila jumlah stek yang diambil terlalu banyak, maka hasil umbi akan berkurang. Interval pengambilan stek dapat dilakukan setiap dua minggu, tergantung pada maca varietas yang dibudidayakan. Stek dari tanaman muda (berumur $<3$ bulan) cenderung memberikan hasil lebih tinggi jika dibandingkan dengan stek kedua atau ketika tanpa pucuk, jika kelembaban lahan optimal, stek yang memiliki pucuk dapat segera melanjutkan pertumbuhannya, sedangkan stek batang bagian kedua atau ketiga tanpa pucuk, lebih dulu membentuk tunas baru dari mata tunas yang terdapat pada buku ruas batang.

\section{Penanaman Bibit}

Sistem penanaman bibit ubi jalar pada saat penanaman, petani tidak mengunakan dengan pupuk kimia atau pupuk kandang, tapi petani setempat langsung menanam diatas bedengan atau gundukan tanah yang sudah disediakan, dan setiap petani mengunakan gabah dari sisa-sisa beras atau padi untuk menjadikan pupuk. Petani mengunakan pupuk gabahh karenakan proses pertumbuhan ubi jalar lebih cepat dan mendapatan hasilnya juga lebih besar, dan ketika berkonsumsi rasanya lebih manis.

\section{Perawatan Ubi Jalar}

Proses perawatan ubi jalar petani melakukan dengan langka-langka yaitu penyiraman, penyulaman, hingga penyiangan gulma. Di lakukan pada saat awal penanaman sampai tumbuh tunas baru. Tanaman ubi jalar adalah tanaman yang tahan kekeringan. Intensitas hujan dua minggu sekali sudah cukup memberikan asupan air, sehingga relatif tidak memerlukan penyiraman secara terus menerus. 
Tabel 8. Perawatan Ubi Jalar

\begin{tabular}{ccc}
\hline \multirow{2}{*}{ Responden } & \multicolumn{2}{c}{ Cara Perawatan Ubi Jalar } \\
\cline { 2 - 3 } & Penyiraman Air & Cabut Rumput \\
\hline 2. & Ada & Ada \\
3. & Ada & Ada \\
4. & Ada & Ada \\
5. & Ada & Ada \\
6. & Ada & Ada \\
7. & Ada & Ada \\
8. & Ada & Ada \\
9. & Ada & Ada \\
10. & Ada & Ada \\
Total & Ada & Ada \\
\hline Sumber Data: Diolah dari Data Primer, 2019 & \\
\hline
\end{tabular}

Tabel 8 menunjukkan bahwa proses perawatan ubi jalar, petani melakukan penyiraman pada saat penanaman sampai tumbuh tunas baru, dan melakukan penyulaman setelah 1-2 minggu penanaman, periksa keseluruhan tanaman. Apabila terdapat tanaman yang gagal tumbuh segera sulam dengan tanaman baru, penyulaman dilakukan dengan mencaput tanaman yang mati dan menggantinya dengan stek batang yang baru.

\section{Pemanenan Ubi Jalar}

Proses pemanenan ubi jalar biasa panen pada usia 6 sampai 7 bulan setelah tanam, ubi diambil dari dalam tanah dengan cara yang berbeda yaitu cangkul dan bajak sapi.

Tabel 9. Pemanenan Ubi Jalar

\begin{tabular}{cccc}
\hline \multirow{2}{*}{ Responden } & $\begin{array}{c}\text { Alat Yang Digunakan Dan } \\
\text { Jangka Waktu Panen Ubi } \\
\text { Jalar di Kelurahan Koya }\end{array}$ & $\begin{array}{c}\text { Bahan Yang } \\
\text { Digunakan }\end{array}$ \\
\cline { 2 - 3 } & \multicolumn{2}{c}{ Alat } & \\
\cline { 2 - 3 } Cangkul & Bajak Sapi & $\begin{array}{c}\text { Jangka } \\
\text { Waktu } \\
\text { Panen 6-7 } \\
\text { bulan }\end{array}$ \\
\hline 1. & Ada & - & Ada \\
2. & Ada & - & Ada \\
3. & Ada & - & Ada \\
4. & - & Ada & Ada \\
5. & - & Ada & Ada \\
6. & Ada & - & Ada \\
7. & - & Ada & Ada \\
8. & Ada & - & Ada \\
9. & Ada & - & Ada \\
10. & Ada & - & Ada \\
\hline Total & $\mathbf{7}$ & $\mathbf{3}$ & $\mathbf{1 0}$ \\
\hline
\end{tabular}

Sumber Data: Diolah dari Data Primer, 2019
Tabel 9 menunjukkan bahwa proses pemanenan, umur ubi jalar berkisar antara 6 sampai 7 bulan. Sebelum pemanenan ubi jalar, petani terlebih dahulu melakukan pemangkasan daun ubi jalar hingga merata dengan tanah dan melakukan pemanenan. Pemanenan ubi jalar dilakukan mengunakan cangkul atau pacul dan bajak sapi.

\section{KESIMPULAN DAN SARAN}

\section{Kesimpulan}

Berdasarkan penelitian yang dilakukan, maka penulis mengambil kesimpulan bahwa kearifan lokal dalam usaha tani ubi jalar di Kelurahan Koya Kecamatan Tondano Selatan Kabupaten Minahasa adalah pada saat penyiapan lahan untuk penanaman ubi jalar petani dapat memilih lahan yang baik dengan cara melihat warna dan jenis tanah. Petani ubi jalar juga menggunakan gabah padi sebagai penyubur tanah dan tanaman agar hasil panen ubi jalar yang dipanen lebih besar.

\section{Saran}

Usaha tani ubi jalar di Kelurahan Koya Kecamatan Tondano Selatan Kabupaten Minahasa. Petani mempertahankan dalam pengembangan ubi jalar, karena ubi jalar sangat dibutukan oleh setiap konsumen untuk makanan sampingan nasi, dan lainlain. Pemerintah harus memperhatikan petani setempat agar dalam usaha tani ubi jalar semakin meningkat dan semakin berkembang dalam usaha mereka.

\section{DAFTAR PUSTAKA}

Jamrianti, R.2009. Ubi Jalar, Saatnya Menjadi Pilihan. Artikel Iptek. 20 Desember 2009.

Sasongko, Lutfi Aris, Helmy Purwanto dan Renan Subantoro. 2008. Penumbuhan Industri Tepung Lokal Melalui Pemberdayaan Kelompok Petani untuk Mendukung Ketahanan Pangan Di Jawa Tengah. Laporan Penelitian. LP3M Unwahas dan Balitbang Jateng.

Widyastuti, C.A., 1994, "Peranan Wanita Suku Dani dalam Mempertahankan Kelangsungan Ubi jalar sebagai Ma-kanan Pokok di Kabupaten Irian Jaya." Edisi Khusus Balittan Malang, No. 3, hal. 353-360. 